$\begin{array}{r}\text { ANGIELS } \\ \text { NEW PERSPETTUE5 } \\ \hline\end{array}$

ANELOPHONE WORLD

\section{Angles}

New Perspectives on the Anglophone World

$2 \mid 2016$

New Approaches to the Body

\title{
And: A Complex Little Word at the Heart of Janet Frame's Language
}

\section{Wilfrid Rotgé}

\section{(2) OpenEdition \\ 1 Journals}

\section{Electronic version}

URL: https://journals.openedition.org/angles/1956

DOI: 10.4000/angles. 1956

ISSN: 2274-2042

\section{Publisher}

Société des Anglicistes de l'Enseignement Supérieur

\section{Electronic reference}

Wilfrid Rotgé, "And: A Complex Little Word at the Heart of Janet Frame's Language ", Angles [Online], 2 I 2016, Online since 01 April 2016, connection on 10 June 2022. URL: http://journals.openedition.org/ angles/1956 ; DOI: https://doi.org/10.4000/angles. 1956

This text was automatically generated on 10 June 2022 .

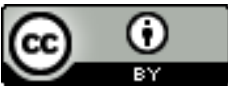

Angles est mise à disposition selon les termes de la Licence Creative Commons Attribution 4.0 International. 


\title{
And: A Complex Little Word at the Heart of Janet Frame's Language
}

\author{
Wilfrid Rotgé
}

1 My starting point is the shortest story in The Lagoon and Other Stories, a collection published in 1951 by New Zealand writer Janet Frame. The 337 word-long story is "The Birds Began to Sing" - it can easily be found on the Internet. The following lines are taken from the beginning of the story, and make up approximately one-third of the text:

The birds began to sing. There were four and twenty of them singing, and they were blackbirds.

And I said, what are you singing all day and night, in the sun and the dark and the rain, and in the wind that turns the tops of the trees silver?

We are singing, they said. We are singing and we have just begun, and we've a long way to sing, and we can't stop, we've got to go on and on. Singing.

The birds began to sing.

I put on my coat and I walked in the rain over the hills. I walked through swamps full of red water, and down gullies covered in snowberries, and then up gullies again, with snow grass growing there, and speargrass, and over creeks near flax and tussock and manuka. (Frame 1997: 157-58)

2 At the heart of this text is the little connecting word and. This in itself is not surprising, considering how often basic coordinators are used in every language around the world. According to the Oxford English Dictionary and based on the Oxford English Corpus, which contains over a billion words, and is the fifth most common word in the English language, following the, be (in all of its conjugated forms), to and of. ${ }^{1}$

It can thus be claimed that and is at the very heart of the language. What is more surprising, however, is to find so many instances of and in a literary text, particularly one with very little dialogue.

Given the widespread use of and in every type of discourse, one might surmise that this little word is semantically as well as stylistically unimportant. I will attempt to demonstrate that there is an underlying complexity beneath this apparent simplicity. 


\section{Simplicity at the heart of Janet Frame's language}

5 What are the stylistic characteristics of this story? As it is very short, the reader may get the impression that it was not written for the adult reader, or that it may even have been written by a child - as it happens, Janet Frame has been criticized for writing 'like a child'.

\subsection{A childlike style}

6 The vocabulary is simple, apart from two words that refer to nature (tussock and manuka, a plant native to New Zealand) and one borrowed from the field of music (vivace andante). It is quite visual and describes the narrator's immediate environment (rain, hills, house, hand, head, body, sing, walk).

7 This childlike style is also reflected in numerous repetitions: the phrase the birds began to sing appears three times (not including the title of the story); the five words that make it up, each pronounced three times, add up to 15 , or nearly $5 \%$ of the 377 words that make up the story.

8 The verb sing is used 14 times, the noun song 5 times, for a total of 19 occurrences of sing/song out of 377 words, or over $5 \%$ of the story. Three pronouns are used in abundance: I, we and they (39 occurrences not including my, your, them, or over $10 \%$ of the words); introductory there (there was/were) is used three times, two of them being there were four and twenty of them singing.

9 One sentence - which is actually a whole paragraph - actually begins with and: And I said ( $2^{\text {nd }}$ paragraph). This is contrary to the stylistic rule that English-speaking adults, particularly writers, are supposed to abide by, which is: "Don't start a sentence with and". The reasoning behind this 'rule' is that this coordinator is supposed to be more structural than cohesive. ${ }^{2}$

10 Anthropomorphism in the story (the birds reply to the narrator's query) reinforces the impression of a childlike atmosphere, coupled with a heightened level of subjectivity, resembling that of children, reflected in the construction and I, which is used eight times throughout the narrative. The narrator systematically repeats $I$ after and, wherever such a repetition is optional: I put on my coat and I walked... / I sat on the stairs in the front and I listened. The pronoun is more often not repeated (I put on my coat and walked...) in English than it is repeated, unlike French, which expects the repetition of the pronoun.

11 Furthermore, the story has only two actants: the birds and $I$, and $I$ is the implicit or explicit subject of nearly half the verbs.

\subsection{A childlike syntax}

12 At the heart of Frame's language we also find childlike syntax. Several of the sentences follow the "Subject Verb Object/complement" order, as for instance: I put on my coat / They were blackbirds / I saw a pine tree on top of a hill.

13 The adult reader is sometimes compelled to mentally re-insert commas, as in the sentence I like to see vivace andante words by music by performed by written for, which is more easily read: I like to see vivace, andante, words by, music by, performed by, written for. 

two clauses, compared to seven non coordinating markers, to which we must add two instances of inter-clausal but. There are very few cases of syntactic embedding and few logical connectors (two buts and one although).

And is used 20 times to link clauses, but there are 35 occurrences of and overall. In the remaining 15 occurrences, and connects noun phrases, prepositional phrases and cardinal numbers. The proportion of ands compared to the rest of the text is very high ( 35 occurrences in 377 words, or a little over $9 \%$ of the text), which also confirms that it is at the heart of the story. We can compare this to the findings of a study carried out by Jean-Rémi Lapaire (2005) on ten works of fiction ${ }^{3}$ published between 1888 and 1922, in which the coordinators and, or, but and nor account for only $4 \%$ of the text.

The total number of coordinators (including 2 occurrences of but) make up roughly $10 \%$ of the story (37 out of 377); and and represents nearly 95\% of the coordinators (compare with the figures put forth by Lapaire [2005], which vary between $68 \%$ and $80 \%$ ). This very high proportion is also in keeping with a childlike style, in that and is the first conjunction to appear in language acquisition.

17 The author uses 141 different words in this 377-word story. Of the first 377 words of Virginia Woolf's novel Mrs Dalloway, there are 199 different words. The quantitative difference turns out to be less that what one might have expected. However, the types of words used vary greatly between the texts - highly referential, descriptive vocabulary in the story; vocabulary associated with meditation and thought, feelings, and assessment, alongside cabbages, cauliflowers and creaking doors in the novel.

\subsection{A childlike universe}

Another characteristic of the story is borrowings from nursery rhymes, as can be seen in:

- the archaic expression four and twenty (There were four and twenty of them singing);

- the explicit echo of the nursery rhyme Sing a song of sixpence (also called Blackbirds in a pie), in which we have the four and twenty blackbirds and the birds began to sing: "Sing a song of sixpence a pocket full of rye, / Four and twenty blackbirds baked in a pie. When the pie was opened the birds began to sing" ${ }^{\prime \prime}$

This echo of the nursery rhyme, and thus of a literary genre meant for children, is unmistakable in Frame's story, which clearly presents us with a childlike universe using a child's words.

What I'm interested in now is the nature of the relationships that the coordinator and creates, as well as the illusion of a simple, unequivocal meaning of and. When two units are connected in this way, even by children, the resulting relationship is rarely as simple as merely adding a clause (Q) to another (P). In Janet Frame's story, the reader has to map the logical connections between the two clauses him/herself. One might get the impression that the reader is expected not to be fooled by what appears to be simple juxtaposition or addition, to look for the complexity behind the simplicity, even if that means reassessing his/her judgment of the narrator's apparent childlike, ingenuous and transparent style. 


\section{And at the heart of Janet Frame's language: a simple heart?}

21 Is and a simple word meaning nothing more than $\mathrm{P}$ and $\mathrm{Q}$, Info $1(=\mathrm{P})$ and Info $2(=\mathrm{Q})$ ? This is unlikely, as the linking of two units by way of a marker, albeit a neutral one, impels us to look for a meaning beyond that of simple syntactic juxtaposition.

Grammar descriptions in use at university level often simply view and as a term linking words belonging to the same category (Swan 2005), or adding information (Hewings 2005). Even Leech and Svartvik (2002) only talk about the syntactic properties associated with and (category of $\mathrm{P}$ and of $\mathrm{Q}$; possibility of omitting and; correlative coordination), and distinguish between "meaning-links" and "positive links" realized by and (2002: 191). Van Dijk (1979: 450) considers it to be a well-known fact that and can have a neutral and vague meaning.

\subsection{The transparency of and}

A relatively simplistic, transparent meaning can be identified in the way and is used when it first appears in Janet Frame's text: four and twenty. It can be paraphrased here by the mathematical sign " "” four and twenty = four + twenty, even though the two units are not equivalent. The expression is archaic in the context of the short story; it is Germanic in origin, although not archaic in German (vierundzwanzig), while "four + twenty" corresponds to a mathematical sum whose product is twenty-four. The sum four and twenty can be expressed as either four plus twenty or four and twenty, and there is no risk in contemporary English of confusion with the archaic cardinal.

Just like in nursery rhymes, it can be argued that in the phrase four and twenty here, and simply realizes an addition, with no further level of meaning. However, such usage, whereby and bears a resemblance with the sign "+", is actually infrequent. Moreover, the addition is not mathematical, in which case the two units could be reversed $(4+3=$ 7 can be reversed: $3+4=7$ ). In language, $P$ and $Q$ can rarely be reversed: there were four and twenty of them singing is not equivalent to there were twenty and four of them singing, which does not mean " 24 " but " 20 and 4". Therefore, even when and seems "neutral", the order $P$ and $Q$ cannot be placed on a par with $Q$ and $P$.

In all day and night, which features in the second sentence of the text, and can also be glossed by "+": all day + all night (with the repetition of the determiner all). However, in this instance, $\mathrm{P}$ and $\mathrm{Q}$ can easily be reversed: what are you singing all night and day is grammatically correct (even though it is less frequent than all day and night)..$^{5}$ There is therefore the temptation to stop at a basic meaning for and in all day and night, "P and $Q$ " - i.e. $Q$ is what comes after $P$, and not to search for a second, indirect meaning. This would, however, be forgetting that, in language, word order construes meaning, and that order engenders another type of meaning, which would, in this case, be indirect.

\subsection{Salience in $P$ and $Q$}

According to the conceptual metaphor identified by Lakoff and Johnson (1980: 128-32), CLOSENESS IS STRENGTH OF EFFECT, that is, proximity produces a stronger link, the relation is stronger between the verb singing and all day $(=\mathrm{P})$ than between singing and all night (= 
Q). Singing all day and night suggests that the singing occurs more often in daytime than at nighttime, precisely because of the textual proximity, or at least that it occurs more naturally during the day. In addition, the most obvious element is often stated first and the most surprising last. The order $\mathrm{P}$ and $\mathrm{Q}$ hence has a raison d'etre and is far from neutral.

It can also be noted that in the construction " $\mathrm{P}$ and Q", $\mathrm{P}$ is salient ${ }^{6}$ compared to that of $\mathrm{Q}$. All day and night does not have the same meaning as all night and day. Once $\mathrm{P}$ is asserted (day), the existence of $\mathrm{Q}$ (the opposite of $\mathrm{P}$, therefore night) goes without saying. The salience can of course be modified by intonation: all day AND night or all day and NIGHT.

The salience placed on $\mathrm{P}$ with respect to $\mathrm{Q}$ varies. It is clear in I listened with my head and my eyes ${ }^{7}(\mathrm{P}$ my head includes $\mathrm{Q}$ my eyes); it would be even clearer in you and I (the speaker is more self-effacing, compared to the addressee) or the king and I.

It is less clear in I walked [...] over creeks near flax and tussock. What type of meaning needs to be reconstructed in flax and tussock, compared to tussock and flax? It can either be assumed that nothing more is said apart from 1. flax; 2. tussock, or it can be posited that a field of vision is established: $\mathrm{P}$ is viewed first, or $\mathrm{P}$ is what is recalled first, in which case $\mathrm{P}$ proves salient. In this case, a quantitative salience distinguishes the referents: what appears in higher quantity is placed more easily in the position of $\mathrm{P}$. Our vision is focused on what is termed in cognitive theory the figure or trajector, as opposed to the ground or landmark (Langacker 2008). In other words, transitory and mobile elements are noticed more than stable elements. If a cat is seen on a roof, our attention will be drawn to the cat more than to the house. Similarly, it is easier to say I saw a house and a cat than I saw a cat and a house, precisely due to the salience of the house.

Logically, such salience disappears when the same lexical item is used in P and Q: we've got to go on and on (see the beginning of the short story) or I stood on a hill and looked and looked (see the middle of the short story). The segment I looked and looked cannot be understood simply in terms of 1. I looked; 2. I looked; it calls for interpretation, that of the intensification expressed by Q. To translate the intensification into French, the adverb encore could be added: "J'ai regardé et regardé encore" or even more likely "J'ai regardé encore et encore". What comes to mind here is another of Lakoff and Johnson's (1980: 127-28) conceptual metaphors: MORE OF FORM IS MORE OF CONTENT, that is, an additional verbal form (repetition of the verb) signals continuity, ${ }^{8}$ as in I looked and looked.

\subsection{Reaching closure with and}

31 If and clearly serves to link elements, the linkage is underscored by an initial dissociation between $\mathrm{P}$ and $\mathrm{Q}$. Unification endorses the difference between two units; and therefore also works to separate and differentiate (Lapaire 2005). The differentiation underscored between $P$ and $Q$ leads to another value, which linguists do not always identify: linking both dissociates, and brings to a close. In $\mathrm{P}$ and $\mathrm{Q}, \mathrm{Q}$ is interpreted as the last element. Another meaning can therefore be established for and: its ability to end a list, which is generally made up of two units. This ability can be associated with the "Oxford comma," i.e. the use of a final comma before and in a list of 
things. It is commonly used in "The Birds Began to Sing" (as in in the sun and the dark and the rain, and in the wind...). hereafter.

\section{Clausal coordination at the heart of Janet Frame's language: a heart to be grasped}

\subsection{Clausal coordination vs. asyndetic coordination}

Clausal coordination (i.e. linking two clauses) is illustrated by the second and third instances of and in the extract: There were four and twenty of them singing and they were blackbirds. And I said, what are you singing all day and night.

Out of the 35 instances of and, 15 involve clausal coordination (42\%), a high rate in a literary text. However, such a frequency is hardly surprising in Frame's writing. As noted earlier, her style is simplistic, and extremely oral. In general, coordination of words or phrases is more frequent in writing, while coordination of clauses more typical in speech (Leech and Svartvik 2002: 15).

In clausal coordination, it would be difficult to defend the hypothesis that the meaning of and could be reduced to its additive value, as if it were written (first line of the story): There were four and twenty of them singing + they were blackbirds.

In asyndetic coordination ${ }^{9}$ (There were four and twenty of them. They were blackbirds), the additive value may be defended, interpreted as Info 1: There were four and twenty of them Info 2: They were blackbirds, but structural juxtaposition is generally understood to be a mental link (temporal, causal, contrastive, Q justifying P, etc.), which can, surprisingly, pave the way for more types of interpretation than coordination based on and (Radden and Dirven 2007: 54). For example, in There were four and twenty of them singing. They were 
blackbirds, P serves as "ground" and Q "figure", hence allowing for a contrastive link: Q (They were blackbirds) takes on a value of counter-expectation with relation to $\mathrm{P} ; \mathrm{Q}$ is stressed more without and than in $\mathrm{P}$ and $\mathrm{Q}$. The effect is more dramatic without the coordinator. ${ }^{10}$

I consider that coordination is not merely a syntactic phenomenon but also reflects a thought process. This position differs from typical descriptions whereby and possesses mainly syntactic properties and is discussed first and foremost in relation to clausal coordination rather than conceptual coordination. I would like to argue that coordination provides not only a syntactic construction but also a vision.

Clausal and conceptual coordination are inseparable: structural juxtaposition relies on mental connection (Lapaire 2005, building on Langacker 1991). Radden and Dirven (2007: 54-55) also use the term "conceptual" to describe the link between P and Q in "P and Q" ("The conceptual link between situations that are coded by means of coordination"), but they reduce the conceptual link to temporal or causal relations. This raises the question of the difference between subordination and coordination, at least when dealing with coordination between two clauses. The problem is, of course, absent from coordination of the type $\mathrm{N}$ and $\mathrm{N}-$ e.g. tussock and manuka -, given that the coordinator cannot be replaced here by a subordinator.

\subsection{Interpreting inter-clausal and}

43 A value of commentary can be observed in the first inter-clausal and of the story: [...] of them singing, and they were blackbirds. The commentary bears on the left-hand context and is reinforced by the comma, which creates emphasis: there were four and twenty of them and on top of that / not only that but they were also blackbirds. Here, the colloquial conjunction plus springs to mind: plus, they were blackbirds, where the value of addition conferred by this item (plus = "+") has been muted into a commentary of the type on top of that, which proves that adding one segment of text to another one is hardly neutral.

A negative or positive interpretation of the commentary will depend on the mental image that the co-utterer has of blackbirds. In British culture, blackbirds are associated with a melodious song (exemplified in the poem by Edward Thomas, Adlestrop, or R.S. Thomas's A Blackbird Singing), ${ }^{11}$ an association confirmed in Janet Frame's story. This first inter-clausal and sets up an intimacy with the reader, as well as an additional interpretation along the lines of "you know what to expect". The second inter-clausal and of the short story reflects a more typical usage: And I said, what are you singing all day and night. And coincides with a clear distinction between two event types, i.e. between the description of the birds and the dialogue with them, hence discounting a causeconsequence interpretation for and. The mental link here is that of consecution, which can be glossed by and then.

Sentence-initial and is used far more frequently than certain style guides would have us believe. Its use here can be justified by the way it softens what would otherwise be an abrupt move between the two events: 1 . Description of the birds; 2 . Interaction between the characters (the narrator and the birds). It reduces the hiatus between two distinct levels of discourse. Thanks to and, the narration appears natural, in cue with readerexpectation, which corresponds to an interpersonal, modal commentary between narrator and reader (Rossette 2013). The first event therefore acts like a natural precursor for the second. 

flow, and also operates an intrinsic link between events, suggesting that things could not have been otherwise. This type of and can therefore be interpreted stylistically and is in no way gratuitous or superficial. Here again, and cannot be reduced to an additive value of the type $\mathrm{P}+\mathrm{Q}$. The relation marked by and gives rise to an interpretation that excludes the reversibility of the processes, which we would have in 2 and 3 is 5 , which can be inverted: 3 and 2 is 5 .

in the fact that, in the first case, the meaning must be construed by the reader. The meaning also presents itself as a form of negotiation. Such an indirect meaning goes hand in hand with a greater degree of syntactic rigidity. The order of the clauses is more of a key component in coordination than in subordination: if $\mathrm{P}$ and $\mathrm{Q}$ are reversed, the condition completely changes (I will write the song and you tell me its name is understood as If I write the song you tell me its name). Conversely, in subordination, the order of the clauses is more flexible: I will write it if you tell me the name of the song corresponds to If you tell me the name of the song I will write it, even if there are certain differences between the two utterances, for example from the point of view of informational salience. This type of utterance proves the limits of the difference between coordination and subordination.

\subsection{Unfathomable and}

51 The interpretation of $\mathrm{P}$ and $\mathrm{Q}$ in the last sentence of the story raises several issues:

So I said what is the name of the song, tell me and I will write it and you can listen at my window when I get the finest musicians in the country to play it, and you will feel so nice to hear your song so tell me the name.

They stopped singing. It was dark outside although the sun was shining. It was dark and there was no more singing. (ADD REF)

52

In this instance of coordination, the reader may detect a double indirect meaning, and therefore a true sense of false naivety in the writing style, as some sentences can only

Angles, 2 | 2016 
be understood thanks to the other sentences of the context. At the end of the story, another level of naivety may be at stake: that of the reader, a reader who may be slightly condescending, having picked up on the simplistic use of coordination instead of the more complex and subtle use of subordination.

Indeed, an initial reading of It was dark and there was no more singing may result in the identification of a causal link: because it was dark, there was no more singing, or: It was dark, and so there was no more singing. This first reading is negated by the previous discourse. First of all, the notion of darkness is ambiguous, due to the preceding sentence: it was dark outside although the sun was shining. The darkness is atypical: vision is obscured by what is not dark (due to the sun shining). ${ }^{12}$ In addition, the causal link "darkness implies no more singing" is negated by what are you singing all day and night, in the sun and the dark, and also, although to a lesser extent, by We are singing and we have just begun, and [...] we can't stop, we've got to go on and on. Singing. It is therefore not the darkness that prevents the birds from singing, as opposed to what could be gathered from a hasty first reading. Basic ornithological knowledge confirms this: blackbirds sing at night. ${ }^{13}$

In fact, what puts an end to the song of the blackbirds is the narrator's wish to give a name to the song, to confine it by way of a label, and simultaneously to imprison it within a script, within sheet music, and therefore to strip it of any freedom and/or spontaneity. To the symbolic death of their song, the birds prefer silence. The end of this free, non-scripted song produces in the narrator an obscure vision (even if there is no real darkness) and at the same time she notes that there was no more singing.

The causal value of and is hence eliminated. Should it therefore be deduced that and has a simple additive value here? Does this utterance read as: 1 . There is darkness; 2 . There is no more singing? This remains a possibility, but another, more complex interpretation may prove more appropriate, that of an emphatic relation, emphasizing $Q$ as opposed to P: Not only was it dark, but there was also no more singing/It was dark and on top of that there was no more singing.

This reading is rendered moot, however, with the preceding text: They stopped singing. It was dark outside although the sun was shining. It was dark and there was no more singing. In other words, $Q$ [there was no more singing] is already contained in They stopped singing and $\mathrm{P}$ is a literal repetition of what precedes [It was dark].

Another interpretation could be that of contrast, with and equivalent to but or and yet: It was dark and yet there was no more singing. This would suggest that the birds sing more generally in the darkness, which is not the case, as they sing "all day and night", with the first element, day, particularly salient.

58 After having ruled out the potential values of causality, emphasis and contrast associated with and, we come back to its initial meaning, that of addition: $Q$ is placed after $\mathrm{P}$, and $\mathrm{P}$ and $\mathrm{Q}$ are interchangeable: There was no more singing and it was dark. Let us recall that the interchangeability of $\mathrm{P}$ and $\mathrm{Q}$ in clausal coordination is rare. It can be posited that, in this final stage of the story, the narrator wants to play on the multiple interpretations synonymous with and, on the ambiguity of the relation between $\mathrm{P}$ and $\mathrm{Q}$, in order for the reader to concede that, after several detours, there is a necessary return to an original, simple uninterpretable value, that of strict juxtaposition. Such an inter-clausal and, which is designed to help the text flow, to iron out the hiatus between two events, ends up reinforcing it, as at the end of the story there is a juxtaposition of 
two events, like two images: 1 . It was dark; 2. There was no more singing. This last instance of and, which provides closure at two levels, blatantly expresses the disarray of the narrator who finds herself confronted with this state of affairs.

Hence we can grasp the false naivety associated with Janet Frame's style. The narrator would not have been able to play with the reader to the same extent if she had used a subordinator, such as because or as (as it was dark there was no more singing).

\section{Conclusion}

After reading Janet Frame's short story "The birds began to sing", we may have the feeling that the narrator, with her false naïve style, might be playing with the reader and his/her desire to interpret the quantitatively most important word of the story, namely the coordinator and. At the core of the short story, the word and may actually suggest that everything we read is somewhat like P and Q: it invites several possible interpretations. In fact, all the short stories that make up The Lagoon and Other Stories may strike us as being simplistic or naïve, but they also invite us, like the lagoon, to look beyond the surface of things or rather: words.

\section{BIBLIOGRAPHY}

Bazin, Claire, and Alice Braun. Janet Frame, The Lagoon and Other Stories: naissance d'une cuvre.

Paris: PUF, 2010.

Bussman, Hadumod. Routledge Dictionary of Language and Linguistics. Trans. and eds. Gregory P. Trauth and Kerstin Kazzazi. London, New York: Routledge, 1996.

Chametzky, Robert. Coordination and the Organization of a Grammar. Chicago: U. of Chicago P., 1987.

Dik, Simon Cornelis. Coordination. Its implications for the theory of general linguistics. Amsterdam:

North-Holland Press, 1968.

Fauconnier, Gilles, and Eve Sweetser. Spaces, Worlds and Grammar. Chicago: U. of Chicago P., 1996.

Frame, Janet. The Lagoon. London: Bloomsbury Publishing, 1997 [1951].

Givón, Talmy. English Grammar. A Function-Based Introduction. Vol. 1. Amsterdam, Philadelphia: John Benjamins, 1993.

Givón, Talmy. Syntax. Vol. 2. Amsterdam, Philadelphia: John Benjamins, 2001.

Halliday, M.A.K., and R. Hasan. Cohesion in English. London: Longman, 1976.

Hewings, Martin. Advanced Grammar in Use. Cambridge: Cambridge UP, 2005.

Huddleston, R., and G.K. Pullum. The Cambridge Grammar of the English Language. Cambridge:

Cambridge UP, 2002.

Jakobson, Roman. Langage enfantin et aphasie. Paris: Minuit, 1969. 
Lakoff, George, and Mark Johnson. Metaphors We Live By. Chicago: U of Chicago P, 1980.

Lakoff, Robin. "If's, and's, and but's about conjunction". Studies in Linguistic Semantics. Charles J. Fillmore and D. Terence Langendoen, eds. New York: Holt, Rinehart and Winston, 1971. 114-49.

Landragin, Frédéric. "Saillance physique et saillance cognitive". Cognition, Représentation, Langage (CORELA) 2.2 (2004). DOI: 10.4000/corela.603

Langacker, Ronald. Foundations of Cognitive Grammar. Vol. 2. Descriptive Application. Stanford: Stanford UP, 1991.

Langacker, Ronald. Cognitive Grammar. A Basic Introduction. Oxford: Oxford UP, 2008.

Lapaire, Jean-Rémi. “Coordination et cognition”. Etudes anglaises 58.4 (2005): 473-495.

Lapaire, Jean-Rémi, and Wilfrid Rotgé. “And, or et but”. Linguistique et grammaire de l'anglais.

Toulouse: PUM, 1991.

Leech, Geoffrey, and Jan Svartvik. A Communicative Grammar of English. London: Longman, 2002.

Oirsouw, Robert R. van. Deletion Processes in Coordinate Structures in English. Cambridge: Cambridge UP, 1981.

Oirsouw, Robert R. van. The Syntax of Coordination. London: Croom Helm, 1987.

Radden, Günter, and René Dirven. Cognitive English Grammar. Amsterdam: John Benjamins, 2007.

Rossette, Fiona. “And-Prefaced Utterances: From Speech to Text”. Anglophonia 34 (2013): 105-135. DOI: 10.4000/anglophonia.234

Swan, Michael. Practical English Usage. Oxford: Oxford UP, 2005.

Sweetser, Eve. From Etymology to Pragmatics. Cambridge: Cambridge UP, 1990.

Van Dijk, T. “Pragmatic connectives”. Journal of Pragmatics 3.2 (1979): 447-456.

\section{NOTES}

1. Archived: https://web.archive.org/web/20160314215542/http://oxforddictionaries.com/ words/the-oec-facts-about-the-language

2. "The 'and' relation is felt to be structural and not cohesive, at least by mature speakers; this is why we feel a little uncomfortable at finding a sentence in written English beginning with And, and why we tend not to consider that a child's composition having and as its dominant sentence linker can really be said to form a cohesive whole" (Halliday and Hasan 1976: 233).

3. Lady Windermere's Fan, An Ideal Husband, The Picture of Dorian Gray (Oscar Wilde), Jacob's Room, The Voyage Out (Virginia Woolf), Peter Pan (J.M. Barrie), A Room with a View (E.M. Forster), The Italian Hours, The Europeans, The Reverberator (Henry James).

4. The nursery rhyme continues: “Oh wasn't that a dainty dish to set before the king? / The king was in his counting house counting out his money, / the queen was in the parlour eating bread and honey / The maid was in the garden hanging out the clothes, / When down came a blackbird and pecked off her nose!"

5. A casual Google search elicits almost 6 million references for all night and day, and more than 17 million for all day and night.

6. "A salient item is what first comes to mind, and what captures our attention. This property [...] applies to discursive entities boasting certain lexical, syntactic, and semantic characteristics, as well as specific phonology and prosody in oral discourse or layout and font in written discourse. The notion of salience therefore involves a figure which detaches itself from a background, 
whether it be due to physical aspects of the spoken or written word, or more semantic or cognitive aspects to do with the interpretation of the utterance. That is why physical salience and cognitive salience can be distinguished, in order to grasp phenomena which come into play in the construction of similar meanings or antonymic meanings." (Landragin 2004; my translation).

7. Here is the context from which the quote has been taken: “I wasn't singing. I tried to sing but I couldn't think of the song. / So I went back home to the boarding house where I live, and I sat on the stairs in the front and I listened. I listened with my head and my eyes and my brain and my hands. With my body. / The birds began to sing."

8. Reduplication applied to verb indicates continuation or completion (Lakoff and Johnson 1980: 128).

9. Asyndetic coordination is the omission of coordinators from constructions in which they would normally be used, as in: "Are all thy conquests, glories, triumphs, spoils, / Shrunk to this little measure?" (Shakespeare, Julius Caesar, Act 3, Scene 1).

10. At least this is the case when and is used instead of asyndeton, which is not always possible, as in I listened with my head and my eyes and my brain and my hands. With my body, as the segment With my body corresponds to a hypernym here with respect to the previously mentioned notions (head, eyes, brain, hands). It would therefore be difficult to place and in front of With my body.

11. "It seems wrong that out of this bird,/ Black, bold, a suggestion of dark / Places about it, there yet should come / Such rich music, as though the notes / Ore were changed to a rare metal / At one touch of that bright bill." R.S. Thomas.

12. All the biographies of Janet Frame underline her schizophrenia. The sentence It was dark outside although the sun was shining can be interpreted as the trace of a schizophrenic vision of reality: the contradiction marked by the subordinated although does not generally bear on complementary notions. Therefore, the bird is black although it is red is just as surprising, and delirious (in the psychological sense) as darkness in broad daylight. In contrast, It was dark outside although it was noon is not delirious: here, there is no contradiction, but rather a concession as regards logic because normally it is not dark at midday.

13. The reader may also have in mind the Beatles' song Blackbird: "Blackbird singing in the dead of night,/ Take these broken wings and learn to fly/ All your life, You were only waiting for this moment to arise."

\section{ABSTRACTS}

The aim of this paper is to provide an explanation of Janet Frame's short story "The Birds Began to Sing" through a detailed study of the grammatical marker "and", using concepts borrowed from cognitive grammar and the "theory of enunciation". It also attempts to show how linguistic theory can be applied to a literary text, which is not used just as a linguistic corpus but analyzed in its literary specificity. The coordinator "and", which is often perceived semantically as well as stylistically as unimportant, lies at the heart of Janet Frame's short story. It gives it meaning and reveals an underlying complexity beneath the short story's apparent simplicity and ultimately false naivety.

Le but de cet article est de proposer une explication à la nouvelle de Janet Frame intitulée «The Birds Began to Sing", grâce à une analyse détaillée du marqueur grammatical "and", en 
utilisant des concepts empruntés à la grammaire cognitive et aux théories de l'énonciation. Il tente également de montrer comment la théorie linguistique peut s'appliquer à un texte littéraire, utilisé non pas simplement comme un corpus linguistique, mais analysé dans sa spécificité littéraire. Le coordonnant «and», qui est souvent considéré comme étant sémantiquement et stylistiquement peu important, se trouve au cœur de la nouvelle de Janet Frame. Il lui donne un sens et fait apparaître une complexité sous-jacente à la simplicité apparente de la nouvelle, et finalement une fausse naïveté.

\section{INDEX}

Keywords: Frame Janet, short story, literature, linguistics, cognitive grammar, coordinator, conjunction

Mots-clés: Frame Janet, nouvelle, littérature, linguistique, grammaire cognitive, coordonnant, conjonction

\section{AUTHOR}

\section{WILFRID ROTGÉ}

Wilfrid Rotgé is Professor of linguistics and phonology at Paris Sorbonne University. He directs CeLiSo (Centre de Linguistique en Sorbonne), a research group that focuses on the grammar and phonology of English, Germanic and Slavic languages. Contact: rotge [at] wanadoo.fr 